\title{
Skin Manifestation among HIV Patients and Its Correlation with CD4 Count and WHO Clinical Staging in Jimma University Specialized Hospital, Southwest Ethiopia
}

\section{Abraham Tamirat Gizaw ${ }^{1 *}$ and Meron Ageze ${ }^{2}$}

${ }^{1}$ Public Health and Medical Sciences College, Jimma University, Ethiopia

${ }^{2}$ Department of Medicine, Public Health and Medical Sciences College, Jimma University, Ethiopia

\begin{abstract}
Background: More than $90 \%$ of human immunodeficiency virus (HIV+) infected patients develop skin lesions at some time throughout the course of the disease. Several skin diseases have proved to be sensitive and useful indicators of progression of HIV+ infection. Although these conditions may be seen in general healthy population, their occurrence in patients with acquired immunodeficiency syndrome is often atypical, more severe and explosive.
\end{abstract}

Objective: The aim of the study was to assess the magnitude and prevalence of skin manifestation among HIV patients in JUSH ART Clinic.

Methods: A retrospective study was conducted among HIV patients in JUSH ART Clinic using a structured data collection format and the data was collected from patient's record (card) and was analyzed by using SPSS version 20. The result was presented using numbers, ratios and tables.

Results: Of 268 HIVIAIDS, patients who have follow-up in Jimma University Specialized Hospital (JUSH) Antiretroviral therapy (ART) clinic $137(51.1 \%)$ were having skin manifestations. The commonest type of skin lesion identified was Herpes Zoster, $74(54 \%)$. This study showed that HIV positive (HIV+) patients with advanced stages of skin disorders had relatively lower CD4+ cell counts. Skin manifestation was significantly associated with WHO clinical stage with $P=0.019$ and $C D 4+$ cell count with a $P$-value 0.0001

Conclusion: Skin diseases are highly prevalent among HIV- Positive patients and the frequency and number of these manifestations are well correlated to the patient's immune status and World Health Organization (WHO) staging. Therefore, examination of skin disorders, as early diagnosis and management of skin problems will improve the quality of life in HIV positive patients.

Keywords: Skin manifestation; CD4 count; WHO staging; JUSH

\section{Background}

Dermatologic problems occur in $>90 \%$ of patients with Human Immunodeficiency Virus (HIV) infection. Several skin diseases have proved to be sensitive and useful indicators of progression of HIV infection. Although these conditions may be seen in general healthy population, their occurrence in patients with acquired immunodeficiency syndrome is often atypical, more sever, explosive, extensive or resistant to therapy. Cutaneous manifestations of HIV disease can be seen throughout the course of HIV infection. Among the more common nonneoplastic problems are seborrheic dermatitis, folliculitis and opportunistic infections [1].

Problems with the skin are among the main reasons for seeking care, accounting for up to $24 \%$ of primary care visits, and are one of the most common causes of morbidity [2]. Transmissible processes, including infections and infestations, make up the majority of skin disease in many Sub-Saharan African countries accounting for $85 \%$ of skin disease in Tanzania, 78\% in Malawi, 71.5\% in Ethiopia and 40.1\% in Uganda [3]. However, primary care providers may have difficulty diagnosing and treating other important skin diseases which often need referrals to specialized dermatology centers [4].

Patient infected with HIV are significantly more likely to develop any of 17 of 20 most common infectious or inflammatory skin conditions .HIV infected patients may experience a variety of dermatologic manifestation. Many of these are readily treatable. HIV infected persons have higher than normal frequency of cutaneous and systemic reactions to a variety of medications [5].
The magnitude and the prevalence of the problem are helpful in early detection and management of the problem.HIV infection predisposes patients to a variety of opportunistic infection as well as reactivation of latent infections. Especially those who have progressed to the acquired immunodeficiency syndrome (AIDS). Skin Disorder and mucosa are among the most common and earliest clinical manifestation of HIV infection [6].

The study done on the socio-demographic distribution of HIV/ AIDS and skin disease in southwest Ethiopia showed that the majority of the patients were from rural area (65.69\%) and belonged to a low socioeconomic and educational status. Approximately $30.65 \%$ of the patients were housewives, $23.35 \%$ drivers, and $16.78 \%$ laborers. Most common $\mathrm{HIV}+$ related dermatological manifestations were seborrheic dermatitis (74.16\%), xerosis (52.5\%), generalized skin

*Corresponding author: Abraham Tamirat Gizaw, Lecturer and Researcher, Jimma University College of Public Health and Medical Sciences, Department of Health Education and Behavioral Science, Jimma, oromia 378, Ethiopia; Tel: 0924354843; Fax: 0471113044; E-mail: abrishntamirat@gmail.com

Received December 21, 2016; Accepted January 17, 2017; Published January 23, 2017

Citation: Gizaw AT, Ageze M (2017) Skin Manifestation among HIV Patients and Its Correlation with CD4 Count and WHO Clinical Staging in Jimma University Specialized Hospital, Southwest Ethiopia. J AIDS Clin Res 8: 657. doi: 10.4172/2155-6113.1000657

Copyright: @ 2017 Gizaw AT, et al. This is an open-access article distributed unde the terms of the Creative Commons Attribution License, which permits unrestricted use, distribution, and reproduction in any medium, provided the original author and source are credited. 
hyperpigmentation 56 (46.67\%), onychomycosis $53(44.16 \%)$, pruritic papular eruption $27(22.5 \%)$, oral candidiasis 21 (17.5\%), photo dermatitis $21(17.5 \%)$ and scabies $4(3.33 \%)$ [7].

A prospective observational study of 2-year duration carried out in the Department of Pathology of a tertiary referral center [8]. A total of 110 known HIV positive patients of all ages with symptomatic skin lesions attending skin and venereal disease outpatient department and Anti-Retroviral Therapy Clinic at this center were included in the study. Out of total 110 known HIV infected patients, 74 were males and 36 were female patients. Maximum numbers of cases were seen between 31 and 40 years of age group. Average age in the study was 34 years. CD4+ cell count was correlated in 70 cases. Out of $70 \mathrm{HIV}+$ patients, 42 (59\%) patients had CD4+ cell count $<200 \mathrm{cell} / \mathrm{mm}^{3} .10$ (15\%) patients showed CD4+ cell counts between 200 and 350 cell $/ \mathrm{mm}^{3}, 11$ patients had CD4+ cell count counts from 350 to 500 cell $/ \mathrm{mm}^{3}$ and 7 (10\%) patients had CD4+ cell count $>500 \mathrm{cell} / \mathrm{mm}^{3}[9]$.

The smallest percentage of African HIV positive patients reported else were as developing herpes Zoster is 7\% (Namibia Hospital, Kampala, Uganda) and the largest is $23 \%$. But the larger the number of patients in the series, the closer the percentage approximates to $15 \%$ [10].

In Ethiopia from study done showed that from a total of 8,622 HIV/AIDS positive cases, 172 (2\%) had skin rashes, 1293 (15\%) had recurrent herpes Zoster, 1466 (17\%) had generalized pruritic dermatitis, 1724 (20\%) had oropharyngeal candidiasis, 86 (1\%) had chronic herpes simplex and $34(0.4 \%)$ had Kaposi's sarcoma [11].

\section{Methods}

\section{Study design and setting}

This was a retrospective cross sectional study using data available as employed from March 20, to April 27, 2016 in Jimma University Specialized Hospital. The hospital (JUSH) is located in Jimma City, $357 \mathrm{~km}$ away from Addis Ababa to southwest Ethiopia. The hospital is a referral centre for the Southwestern part of Ethiopia. Currently it became the only teaching and referral hospital in the southwestern part of the country. It provides services for approximately 9000 inpatient and 80000 outpatient attendances a year coming to hospital from the catchment population of about 15,000 million people.

\section{Study sample}

The study sample included all 220 medical records of patients who visit JUSH ART Clinic for the first time after diagnosis during the study period and those have full information were included. However, incomplete records were excluded.

\section{Study variables}

The outcome variables for this study were Skin manifestation, WHO Clinical Staging, type of skin lesion were extracted as variable from the record. The predictor variables like demographic variables were extracted from records.

\section{Data processing, analysis, interpretation and presentation}

Te data were entered in double EpiData software, checked for missing values and outliers and analyzed using SPSS version 20. Descriptive statistics were used to describe the study population in relation to relevant variables. To identify association of skin manifestation with CD4+ cell count and WHO staging the negative binomial regression model was used to control the effect of confounders. Test was two-sided and $\mathrm{P}<0.05$ was considered statistically significant.

\section{Results}

\section{Socio-demographic characteristics}

The study involved 268 HIV+ patients who were having followup to JUSH ART Clinic. From the study population 163 (60.8\%) were female and 105 (39.2\%) were males. Most of the patients 149 (55.6\%) were within the age group of $15-30$ years while $3(1.1 \%)$ were in the age group of $>50$ years. One hundred and forty three $(53.4 \%)$ were from rural area (Table 1).

From the study population 137 (51.1\%) of them were having skin manifestations. $84(31.3 \%)$ were female and $53(19.8 \%)$ were males. Most of the patients 67 (25\%) were in the age group 15-30 years and 60 (22.4\%) were in the age group of 31-50 years.

Out of 268 HIV+ patients who were on ART, 137 (51.1\%) had skin manifestations. Among them 74 (54\%) were having Herpes Zoster followed by oral candidiasis31 (22.6\%), while $6(4.4 \%)$ were having Moluscum Contangiosum and only $1(0.7 \%)$ patient has other (minor mucocutaneous skin lesion).

Appropriate diagnosis and management of drug hypersensitivity reactions are essential, especially in patients with very low CD4+ T-cell count and multiple opportunistic infections. In our study $3(2.2 \%)$ the $\mathrm{HIV}+$ patient had showed hypersensitivity reaction. The female to male ratio regarding hypersensitivity reactions was 2:1 (Table 2).

Regarding the CD+ cell counts, most of HIV+ patients 55 (40.1\%) had CD4+ cell counts $<200$ cell $/ \mathrm{mm}^{3}$ and $54(39.4 \%)$ had CD $4+$ cell count $200-350 \mathrm{cell} / \mathrm{mm}^{3}$. Skin manifestation is significantly associated with $\mathrm{CD} 4+$ cell count $\mathrm{P}=0.0001$.

From the study population 137 (51.1\%) of them were having skin manifestations. Approximately $61(44.5 \%)$ were found in the WHO stage III, 55 (40.1\%) in the WHO stage II and 20 (14.6\%) found in stage

\begin{tabular}{|c|c|c|c|}
\hline Characteristics & & No & $\%$ \\
\hline \multirow[t]{3}{*}{ Sex } & M & 105 & 39.2 \\
\hline & $\mathrm{F}$ & 163 & 60.8 \\
\hline & Total & 268 & 100.0 \\
\hline \multirow[t]{5}{*}{ Age } & $<15$ & 8 & 3 \\
\hline & $15-30$ & 149 & 55.6 \\
\hline & $31-50$ & 108 & 40.8 \\
\hline & $>50$ & 3 & 1.1 \\
\hline & Total & 268 & 100.0 \\
\hline \multirow[t]{3}{*}{ Residence } & Urban & 125 & 46.6 \\
\hline & Rural & 143 & 53.4 \\
\hline & Total & 268 & 100.0 \\
\hline \multirow{5}{*}{ Marital Status } & Single & 45 & 16.8 \\
\hline & Married & 130 & 48.5 \\
\hline & Divorced & 71 & 26.5 \\
\hline & Widowed & 22 & 8.2 \\
\hline & Total & 268 & 100.0 \\
\hline \multirow{7}{*}{ Occupation } & Student & 18 & 6.7 \\
\hline & Driver & 7 & 2.6 \\
\hline & $\begin{array}{l}\text { Government } \\
\text { Employee }\end{array}$ & 138 & 51.5 \\
\hline & Bed ridden & 27 & 10.1 \\
\hline & House Wife & 58 & 21.6 \\
\hline & Other & 20 & 7.5 \\
\hline & Total & 268 & 100.0 \\
\hline
\end{tabular}

Table 1: Socio demographic distribution of HIVIAIDS patients in JUSH ART Clinic, southwest Ethiopia, Oromia region from January 1, 2015-December 31, 2015. 
Page 3 of 4

\begin{tabular}{|c|c|c|c|c|c|c|}
\hline \multirow{3}{*}{ Type of skin lesion } & \multicolumn{4}{|c|}{ Sex } & \multicolumn{2}{|c|}{ Total } \\
\hline & \multicolumn{2}{|c|}{$\mathbf{M}$} & \multicolumn{2}{|c|}{$\mathbf{F}$} & \multirow[b]{2}{*}{ Number } & \multirow[b]{2}{*}{ Percent (\%) } \\
\hline & Number & Percent (\%) & Number & Percent (\%) & & \\
\hline Herpes Zoster & 30 & 21.9 & 44 & 32.1 & 74 & 54 \\
\hline Oral candidiasis & 12 & 8.8 & 19 & 13.9 & 31 & 22.6 \\
\hline Moluscum Contangiosum & 2 & 1.5 & 4 & 2.9 & 6 & 4.4 \\
\hline Orolabial herpes & 1 & 0.7 & 5 & 3.6 & 6 & 4.4 \\
\hline Genital herpes & 2 & 1.5 & 2 & 1.5 & 4 & 2.9 \\
\hline Seborrhoeic dermatitis & 2 & 1.5 & 2 & 1.5 & 4 & 2.9 \\
\hline Drug reaction & 1 & 0.7 & 2 & 1.5 & 3 & 2.2 \\
\hline Pruritic papular eruptions & 1 & 0.7 & 2 & 1.5 & 3 & 2.2 \\
\hline Kaposis Sarcoma & 0 & & 1 & 0.7 & 1 & 0.7 \\
\hline Chancroid & 0 & & 1 & 0.7 & 1 & 0.7 \\
\hline Norwegian scabies & 1 & 0.7 & 0 & & 1 & 0.7 \\
\hline Oral hairy leukoplakia & 1 & 0.7 & 0 & & 1 & 0.7 \\
\hline Psoriasis & 0 & & 1 & 0.7 & 1 & 0.7 \\
\hline Folliculitis & 0 & & 0 & & 0 & \\
\hline Atopic dermatitis & 0 & & 0 & & 0 & \\
\hline Condyloma acuminatum & 0 & & 0 & & 0 & \\
\hline Others & 0 & & 1 & 0.7 & 1 & 0.7 \\
\hline Total & 53 & 38.7 & 84 & 61.3 & 137 & 100 \\
\hline
\end{tabular}

Table 2: Distribution of skin lesions in HIVIAIDS patients by Sex in JUSH ART Clinic, Southwest Ethiopia, Oromia region from January 1, 2015-December 31, 2015.

\begin{tabular}{|l|c|c|c|c|c|c|}
\hline \multirow{2}{*}{ Type of skin lesion } & \multicolumn{5}{|c|}{ WHO Clinical Staging } \\
\hline & I & II & III & IV & Frequency & Percent \\
\hline Herpes zoster & 0 & 44 & 26 & 4 & 74 & 54 \\
\hline Orolabial herpes & 0 & 1 & 5 & 0 & 6 & 4.4 \\
\hline Condyloma acuminatum & 0 & 0 & 0 & 0 & 0 & 0 \\
\hline PPE & 0 & 1 & 2 & 0 & 3 & 2.2 \\
\hline MoluscumContangiosum & 0 & 3 & 2 & 1 & 6 & 4.4 \\
\hline Kaposis Sarcoma & 0 & 0 & 0 & 1 & 1 & 0.7 \\
\hline Chancroid & 0 & 1 & 0 & 0 & 1 & 0.7 \\
\hline LGV & 0 & 0 & 0 & 0 & 0 & 0 \\
\hline Genital herpes & 0 & 1 & 2 & 1 & 4 & 2.9 \\
\hline Oral candidiasis & 0 & 0 & 19 & 12 & 31 & 22.6 \\
\hline Genital candidiasis & 0 & 0 & 0 & 0 & 0 & 0 \\
\hline Oral hairy leukoplakia & 0 & 0 & 0 & 1 & 1 & 0.7 \\
\hline psoriasis & 0 & 0 & 1 & 0 & 1 & 0.7 \\
\hline folliculitis & 0 & 0 & 0 & 0 & 0 & \\
\hline Norwegian scabies & 0 & 0 & 1 & 0 & 1 & 0.7 \\
\hline Seboricdermatitis & 0 & 2 & 2 & 0 & 4 & 2.9 \\
\hline Atopic dermatitis & 0 & 0 & 0 & 0 & 0 & 0 \\
\hline Drug reaction & 1 & 1 & 1 & 0 & 3 & 2.2 \\
\hline Others & 0 & 1 & 0 & 0 & 1 & 0.7 \\
\hline Total & 1 & 55 & 61 & 20 & 137 & 100.0 \\
\hline
\end{tabular}

$\chi^{2}=77.192 ; \mathrm{DF}=3 ; \mathrm{P}=0.000$

Table 3: Skin lesion occurring in each WHO clinical stage in JUSH ART Clinic Southwest Ethiopia, Oromia region from January 1, 2015-December 31, 2015.

IV, skin manifestation was significantly associated with WHO clinical staging of HIV/AIDS P=0.0198 [12] (Table 3).

\section{Discussion}

Most studies done on the prevalence of skin manifestation among HIV/AIDS patients are population based; those conducted using a hospitalized population are scarce, which limites comparison of the study.

In this study, among HIV/AIDS patients who were already antiretroviral therapy and the data retrieved from January to December showed that the overall prevalence of skin manifestation was 137
$(51.1 \%)$. The result is comparable with study done in Ethiopia in the sero-epidimilogical survey that was $55.4 \%$. However, the study conducted in India on HIV+ patients, skin manifestation was 110 $(87.6 \%)$ which is significantly higher [13].

This variation in the prevalence of skin manifestation in this study and the above study could be due to the variation in the geographic location, socioeconomic status and method of determination of the sample size. The alternative explanation for this variation could be this study is done among patients who have follow-up.

The prevalence of the problem in HIV/AIDS positive patients is likely to be a combined result of the presence of other opportunistic infection which further cause decreases the immunity.

In this study, the most common type of skin lesion is Herpes Zoster 74 (54.0\%). This value is higher than the study done in Ethiopia from January 1986 to October 1993, which were Herpes Zoster skin lesion (17\%) in Ethiopia and (23\%) in Uganda. This higher value could be because most of the patients have low CD4+ cell count, which is significantly associated with skin manifestation.

In study done by Kumarasamy et al. [14] of $110 \mathrm{HIV}$ infected patients, CD4correlation was done in 70 patients. Maximum patients, i.e., 42 (59\%) had CD4 count below 200, followed by 21 (31\%) patients with CD4 counts between 200 and 500, whereas 7 (10\%) had CD4 counts above 500 . This value is higher than the above study.

Among those patients with skin manifestation 55 (40.1\%) of them were having CD4+ cell count $<200 \mathrm{cell} / \mathrm{mm}^{3}$ and 54 (39.4\%) of HIV+ patients were having CD4+ cell counts between $200 \mathrm{cell} / \mathrm{mm}^{3}$ to 350 cell $/ \mathrm{mm}^{3}$. Only $5(3.6 \%)$ patients had CD4+ cell count $>500$ cell/ $\mathrm{mm}^{3}$ and had skin lesion. Skin manifestation is significantly associated with CD4+ cell count in this study ( $\mathrm{P}=0.0001)$.

In general, in the study the overall prevalence of skin manifestation was high. The most common type of skin lesion was Herpes Zoster. Skin manifestation is associated with CD4+ cell counts and with WHO stage of HIV/AIDS positive patients'. Health professionals should give attention on the early detection of skin manifestations among HIV/AIDS positive patients to prevent severity and its complication. 
Citation: Gizaw AT, Ageze M (2017) Skin Manifestation among HIV Patients and Its Correlation with CD4 Count and WHO Clinical Staging in Jimma University Specialized Hospital, Southwest Ethiopia. J AIDS Clin Res 8: 657. doi: 10.4172/2155-6113.1000657

Clinicians should aware of different half-life of each drug when decided to stop the drug reaction. Knowledge of the metabolism, recognition of the risk factors and the ability to suggest the probability of particular drug as causative are also important points.

\section{Declarations}

\section{Funding}

The work was supported by grants from Jimma University, College of Health Science Ethiopia, for academic purpose. The funders had no impact on the design, conduct and reporting of the study; collection, management, analysis and interpretation of the data; and preparation, review, or approval of the manuscript.

\section{Availability of data and materials}

Upon request, we can offer on-site-access to external researchers to the data analyzed at the SPSS, Jimma University, Ethiopia.

\section{Authors' contributions}

The authors' responsibilities were as follows: MA formulated the study hypothesis together with AT, MA and AT performed the statistical analyses and contributed to the first and final draft of the manuscript. MA and AT contributed to the interpretation of the study results and to the first and final draft of the manuscript.

\section{Ethics approval and consent to participate}

The study was ethically approved by the College of Health, Jimma University Ethical Review Board.

\section{Acknowledgement}

We strongly acknowledge College of Health Sciences Ethical Review Board for timely reviewing and giving us ethical clearance timely. We also acknowledge Jimma University Research and Publication Office for funding this study withou which this might not be possible. We also acknowledge for Jimma University Specialized Teaching Hospital for giving permission to carry this study.

Finally, our deep gratitude goes to the psychiatry department health professionals and record keeping personnel for their great participation to provide us valuable information without which this cannot at all be possible.

\section{References}

1. Dennis L, Kasper Z, Braunwld S, Danalog J, Harrison L (2013) Principle of internal medicine, 18th edition, pp: 33-37.
2. Baldridge JR, Thomashow MF, Hinrichs DJ (1988) Induction of immunity with avirulent Listeria monocytogenes 19113 depends on bacterial replication. Infect Immun 56: 2109-2113.

3. Nnoruka EN (2005) Skin diseases in south-east Nigeria: A current perspective. Int J Dermatol 44: 29-33.

4. Gibbs S (1996) Skin disease and socioeconomic conditions in rural Africa: Tanzania. Int J Dermatol 35: 633-639.

5. Kristensen JK (1991) Scabies and Pyoderma in Lilongwe, Malawi: Prevalence and seasonal fluctuation. Int J Dermatol 30: 699-702.

6. Wiwanitkit V (2004) Prevalence of dermatological disorders in Thai HIV-infected patients correlated with different CD4 lymphocyte count statuses: A note on 120 cases. Int J Dermatol 43: 265-268.

7. Kumarasamy N, Solomon S, Madhivanan P, Ravikumar B, Thyagarajan SP, et al. (2000) Dermatologic manifestations among human immunodeficiency virus patients in south India. Int J Dermatol 39: 192-195.

8. Coopman SA, Johnson RA, Platt R, Stern RS (1993) Cutaneous disease and drug reactions in HIV infection. N Engl J Med 328: 1670-1674.

9. Smith KJ, Skelton HG, Yeager J, Ledsky R, McCarthy W, et al. (1994) Cutaneous findings in HIV-1-positive patients: A 42 month prospective study. Military Medical Consortium for the Advancement of Retroviral Research (MMCARR). J Am Acad Dermatol 31: 746-754.

10. Friedman-Kien AE, Lafleur FL, Gendler E, Hennessey NP, Montagna R, et al (1986) Herpes zoster: A possible early clinical sign for development of acquired immunodeficiency syndrome in high-risk individuals. J Am Acad Dermatol 14: 1023-1028.

11. Nichols L, Balogh K, Silverman M (1989) Bacterial infections in the acquired immune deficiency syndrome. Clinicopathologic correlations in a series of autopsy cases. Am J ClinPatho 92: 787-790.

12. Dover JS, Johnson RA (1991) Cutaneous manifestations of human immunodeficiency virus infection. Part II. Arch Dermatol 127: 1549-1558.

13. Frommel D, Tekle-Haimanot R, Verdier M, Negesse $Y$, Bulto T, et al. (1994) HIV infection and leprosy: A four-year survey in Ethiopia. Lancet 344: 165-166.

14. Inserra DW, Bickley LK (2010) Crusted scabies in acquired immunodeficiency syndrome. Int J Dermatol 77: 287-289. 